\title{
Meme Kanseri (MCF-7) Hücrelerinde Krosinin Inflamasyon ve Oksidatif Stres Aracilı Apoptoza Etkileri
}

\author{
Ömer HAZMAN ${ }^{1}$ \\ ${ }^{1}$ Afyon Kocatepe Üniversitesi, Fen Edebiyat Fakültesi, Kimya Bölümü, Biyokimya AD. Afyonkarahisar. \\ e-posta: omerhazman@hotmail.com, ORCID ID: http://orcid.org/0000-0002-2702-6847 \\ Geliş Tarihi: 18.11.2021 Kabul Tarihi: 26.12.2021
}

\begin{abstract}
Öz
Anahtar kelimeler Kanser; MCF-7

hücreleri; Krosin;

Inflamasyon; Oksidatif stres; Apoptoz

Krosin, safran (Crocus sativus L.) bitkisinin çiçek kısmındaki stigmalarının kurutulması ile elde edilen karotenoid yapılı bir bileşiktir. Sunulan çalışmada krosinin insan meme adenokarsinomu (MCF-7) hücre hattında sitotoksisite düzeyleri ile oksidatif stress, inflamasyon ve apoptoza etkileri belirlendi. MCF-7 hücrelerinde krosinin sitotoksisitesi, MTT (3-4,5-dimetil-tiyazolil-2,5-difeniltetrazolyum bromid) testi ile

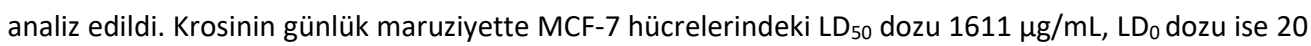
$\mu \mathrm{g} / \mathrm{mL}$ olarak belirlendi. MCF-7 hücrelerinde krosinin antioksidan ve inflamatuvar sisteme etkisini belirleyebilmek amacıyla dört farklı deneysel grup oluşturuldu. Deney gruplarından elde edilen hücre lizatlarında total antioksidan statü (TAS), total oksidan statü (TOS) ve oksidatif stres indeksi (OSI), tümör nekrozis faktör (TNF) $\alpha$, interferon (IFN) $\gamma$, Interlöykin 1 (IL1) $\beta$ düzeyleri analiz edildi. Krosinin apoptoza etkilerini belirlemek amacıyla ise RT-PCR yöntemiyle apoptotik/antiapoptotik genlere (p53, Bcl-2, TRAIL1, TRAIL2, Bax) ait mRNA ekspresyon düzeyleri analiz edildi. Elde edilen veriler değerlendirildiğinde, krosinin MCF-7 hücrelerinde $L D_{0}$ ve $L D_{50}$ dozlarında proinflamatuvar stokin düzeylerini etkilemeksizin oksidatif stresi artırarak apoptozu uyardığı tespit edildi. Hücre kültürü çalışmaları ile belirlenen, krosinin MCF-7 hücrelerinde antikanserojen etkinliğinin, deney hayvanlarında oluşturulacak modellemeler ile doğrulanması, krosinin kanser tedavisinde olası yararlarını açıklamak adına yararlı olabilir.
\end{abstract}

\section{Effects of Crocin on Inflammation and Oxidative Stress Mediated Apoptosis in Breast Cancer (MCF-7) Cells}

\begin{abstract}
Crocin is a carotenoid compound obtained by drying the stigmas of the flower part of the saffron (Crocus sativus L.) plant. The present study determined the effects of crocin on cytotoxicity, oxidative stress, inflammation, and apoptosis in human breast adenocarcinoma (MCF-7) cell lines. The cytotoxicity of crocin in MCF-7 cells was analyzed by the MTT (3-4,5-dimethyl-thiazolyl-2,5diphenyltetrazolium bromide) assay. The LD50 dose of crocin in MCF-7 cells at daily exposure was determined as $1611 \mu \mathrm{g} / \mathrm{mL}$, and the $\mathrm{LD}_{0}$ dose was determined as $20 \mu \mathrm{g} / \mathrm{mL}$. In order to determine the effect of crocin on the antioxidant and inflammatory system in MCF-7 cells, four different experimental groups was formed. Total antioxidant status (TAS), total oxidant status (TOS), oxidative stress index (OSI), tumor necrosis factor (TNF) $\alpha$, interferon (IFN) $\gamma$, interleukin 1 (IL1) $\beta$ levels in cell lysates obtained from experimental groups were analyzed. In order to determine the effects of crocin on apoptosis, mRNA expression levels of apoptotic/antiapoptotic genes (p53, Bcl-2, TRAIL1, TRAIL2, Bax) were analyzed by the RT-PCR method. When the obtained data were evaluated, it was determined that crocin stimulated apoptosis in MCF-7 cells by increasing oxidative stress without affecting proinflammatory stock levels at $\mathrm{LD}_{0}$ and $\mathrm{LD}_{50}$ doses. Confirmation of the anticarcinogenic activity of crocin in MCF-7 cells, determined by cell culture studies, with models to be created in experimental animals may be helpful to explain the possible benefits of crocin in cancer treatment.
\end{abstract}

Keywords

Cancer; MCF-7 cells;

Crocin; Inflammation;

Oxidative stress;

Apoptosis 


\section{Giriş}

Kadınlar arasında yaygın görülmekte olan meme kanseri, 2020 verilerine göre dünyada en sık görülen kanserler arasında birinci sıraya yükselmiştir (Sung et al. 2021). Meme kanseri ve diğer kanser türlerinin yaygınlığının her geçen gün artıyor olması, bu konuda tedaviye katkı sunabilecek her türlü araştırmayı daha da önemli kılmaktadır. Bu nedenle tedaviye yönelik araştırmalar bilim dünyasının ilgi odağındadır. Hem meme kanserinde hem de diğer kanser türlerinin tedavisinde kullanılan geleneksel yöntemlerin ağır yan etkileri vardır. Bu nedenle yan etkileri azaltabilecek veya daha az yan etkileri olabilecek alternatif yöntemler geliştirilmeye çalışılmaktadır. $\mathrm{Bu}$ bağlamda antioksidanların anti-kanserojen etkinliklerinin araştırılması da önem arz etmektedir.

Krosin, tarih boyunca birçok toplum tarafından farklı hastalıkların tedavisi amacıyla kullanılagelen safran (Crocus sativus L.) bitkisinden elde edilen karotenoid yapıda bir bileşiktir. Bu bileşik safran bitkisinin çiçeklerinde bulunan stigmalarının kurutulması ile elde edilir (Hoshyar and Mollaei 2017). Yapılan araştırmalar krosinin her geçen gün yeni bir farmakolojik etkisinin olabileceğini göstermektedir. Bu etkiler arasında antioksidan (Assimopoulou et al. 2005, Adalı vd. 2016) anti-platelet (LiakopoulouKyriakides and Skubas 1990), nöroprotektif (Soeda et al. 2001), antidiyabetik (Kianbakht and Hajiaghaee 2011, Shirali et al. 2012; Rajaei et al. 2013), antihiperlipidemik (Lee et al. 2005), antiobezite (Hazman et al. 2016), antiapoptotik (Ozkececi et al. 2016) ve anti-kanserojenik (Garcia-Olmo et al. 1999, Chryssanthi et al. 2007) etkinliği gösterilmiştir. Sunulan çalışmada ise krosinin MCF-7 hücre hattında oksidatif stress veya inflamasyon aracılı apoptoza etkileri belirlenmeye çalışılmıştır.

\section{Materyal ve Metot}

Araştırma üç aşamada gerçekleştirilmiştir. illk aşamada krosinin MCF-7 hücrelerinde sitotoksik dozları belirlenmiştir. Deney gruplarına uygulanacak olan krosin dozları belirlendikten sonra deney grupları oluşturulmuştur. İkinci aşamada her grupta en az 5 flask olacak şekilde hücreler üretilmiş, deney gruplarına, belirlenen krosin dozları uygulanmıştır.
Deney gruplarına yapılan uygulamalardan sonra laboratuvar analizlerinde kullanılmak üzere hücre lizatları elde edilmiştir. Üçüncü aşamada ise elde edilen numuneler kullanılarak MCF-7 hücre hattında krosinin oksidatif stress, inflamasyon ve apoptoza etkilerini belirlemeye yönelik laboratuvar analizleri gerçekleştirilmiştir.

\section{1 Çalışmada Kullanılan Hücre Hattı ve Besiyerinin Hazırlanması}

Krosininin meme kanserinde inflamasyon, oksidatif stress ve apoptoza etkilerinin belirlenmesi amacıyla MCF-7 hücreleri kullanılmıştır. MCF-7 hücreleri sıvı azot içinde Anadolu Üniversitesi, Fen Edebiyat Fakültesi, Moleküler Biyoloji ve Genetik Bölümünden temin edilmiştir. MCF-7 Hücrelerinin çoğaltılması için kullanılan besiyeri; \%10 (v/v) Fetal bovine serum (Copricorn), \%1 (v/v) penisilin streptomisin (Sigma), \%1 (v/v) sodyum piruvat (Sigma), \%1 glutamin (Sigma), \% 87 oranında high glukoz DMEM (Sigma) içerecek şekilde hazırlandı. Hücrelere uygulamalar yapıldıktan sonra tüm inkübasyonlar, steril ortamda $\% 5 \mathrm{CO}_{2}$ ve $37^{\circ} \mathrm{C}$ olacak bir ortamı sürekli sağlayan ve dengede tutan $\mathrm{CO}_{2}$ inkübatöründe (Panasonic) gerçekleştirildi.

Krosinin MCF-7 hücrelerindeki sitotoksisite düzeyleri 96 kuyucuklu mikroplate kullanılarak MTT yöntemi ile belirlendi. MTT çözeltisi, uygun $\mathrm{pH} \quad \mathrm{pH}=7,4)$ ortamında PBS (Phosphate buffer saline) içinde 5 $\mathrm{mg} / \mathrm{mL}$ konsantrasyonda olacak şekilde MTT tuzunun (Sigma) çözülmesiyle hazırlandı.

Krosin (Sigma) sitotoksisitesini belirlemek için 0,1-6,4 $\mathrm{mg} / \mathrm{mL}$ aralığındaki konsantrasyonlarda farklı $7 \mathrm{doz}$ tercih edildi. Kontrol grubu olarak planlanan vellere ise krosinin çözücüsü olarak kullanılan besiyeri eklendi. Hücrelere krosin uygulandıktan 24 saat sonra her bir kuyucuğa, kuyucuk hacminin \%10’u oranındaki hacimde MTT çözeltisi ilave edildi. Hücreler bu şekilde 2-4 saat inkübasyona bırakıldı. Inkübasyon sonunda MTT'nin etkisiyle canlı hücrelerde formozan kristalleri oluştu. Kristalleri etkilemeden vellerdeki sıvı kısım pipetle çekildi. Kuyucuklardaki formozan kristalleri üzerine $200 \mu \mathrm{L}$ DMSO eklendi. Böylelikle kuyucuklardaki formozan kristallerinin tekrar çözünmesi sağlandı. Örneklerin optik dansiteleri 540 nm'de, ELISA mikroplate 
okuyucu (Biotek, ELx800) kullanılarak belirlendi. Krosin uygulanmayan deney grubunun (kontrol grubu) hücre canlılığı oranı \% 100 kabul edilerek, her bir dozun hücre canlılığına etkisi ( (\%)Hücre Canlılı̆ı $=\left[(100 *\right.$ Absorbans numune $) /\left(\right.$ Absorbans $\left.\left.\left._{\text {kontrol }}\right)\right]\right)$ hesaplandı. Her bir doza ait hücrelerin canlılık oranları \% olarak ifade edildi (Ersin vd. 2016, Ulaşlı vd. 2013).

Uygulamalar sonucunda kontrol grubuna göre hücre canlıığını \% 50 azaltan krosin dozu, LD ${ }_{50}$ dozu şeklinde ifade edildi. MTT uygulamaları sonucunda kontrol grubuna göre hücre canlılığınını etkilemeyen krosin dozu ise $\mathrm{LD}_{0}$ dozu olarak kabul edilerek çalışmalarda kullanıldı. Uygulamada kullanılan MCF7 hücrelerindeki etkili olan krosine ait lethal dozlar ( $L D_{0}, L_{50}$ gibi), her bir dozun hücrelerde oluşturduğu $\%$ canlılık oranları kullanılarak belirlendi. Lethal dozların hesaplanmasında Epa Probit Analysis Program (Version 1.5) adlı yazılım kullanıldı. Sunulan çalışmada lethal dozlar belirlendikten sonra deney grupları oluşturularak uygulamalara geçildi. Çalışma kapsamında oluşturulan deney grupları Çizelge 1'de sunulmuştur. Deney gruplarına Çizelge 1'de ifade edilen uygulamaların tatbik edilmesi sonucunda elde edilen hücre lizatları kullanılarak biyokimyasal analizler, hücrelerden izole edilen total RNA'lar yardımıyla sentezi gerçekleştirilen cDNA'lar kullanılarak ise analizi planlanan ilgili genlerin mRNA ekspresyon düzeyleri belirlendi.

Çizelge 1. Çalışmada kullanılan deney grupları

\begin{tabular}{|c|c|}
\hline Gruplar & Yapılan Uygulamalar \\
\hline $\begin{array}{l}\text { Grup } 1 \\
\text { Kontrol Grubu }\end{array}$ & $\begin{array}{l}\text { Krosin besiyerinde çözüldüğü için, diğer } \\
\text { gruplara krosin uygulandığı zamanlarda } \\
\text { aynı hacimde besiyeri uygulanan grup }\end{array}$ \\
\hline $\begin{array}{l}\text { Grup } 2 \\
\mathrm{LD}_{0} \text { dozu tedavi } \\
\text { grubu }\end{array}$ & $\begin{array}{l}\text { MTT analizleri sonucunda belirlenen } \mathrm{LD}_{0} \\
\text { dozunda }(20 \mu \mathrm{g} / \mathrm{mL}) \text { krosin uygulanan } \\
\text { grup }\end{array}$ \\
\hline $\begin{array}{l}\text { Grup } 3 \\
\mathrm{LD}_{50} \text { dozu } \\
\text { tedavi grubu }\end{array}$ & $\begin{array}{l}\text { MTT analizleri sonucunda belirlenen } \mathrm{LD}_{50} \\
\text { dozunda }(1611 \mu \mathrm{g} / \mathrm{mL}) \text { krosin uygulanan } \\
\text { grup }\end{array}$ \\
\hline $\begin{array}{l}\text { Grup } 4 \\
\text { Yüksek doz } \\
\text { tedavi grubu }\end{array}$ & $\begin{array}{l}\text { MTT analizleri sonucunda belirlenen } \mathrm{LD}_{50} \\
\text { dozunun iki katı oranda }(3200 \mu \mathrm{g} / \mathrm{mL}) \\
\text { krosin uygulanan grup }\end{array}$ \\
\hline
\end{tabular}

\subsection{Total Protein Analizi}

Elde edilen hücre lizatlarının kullanılmasıyla gerçekleştirilen analizlerden elde edilen sonuçların hesaplanabilmesi amacıyla her bir numunenin total protein seviyesi belirlendi. Numunelerin total protein seviyeleri ticari kit (Fluka) kullanılarak multiplate okuyucu (Biotek ELx-800) yardımıyla 595 nm'de ölçüldü. Bradford (1976) yöntemine gore çalışan kitle birlikte tedarik edilen standart kullanılarak seri dilüsyonlarla hazırlanan 125-4000 $\mu \mathrm{g} / \mathrm{mL}$ konsantrasyonu aralığındaki 6 standart hazırlandı. 96'lık mikroplate üzerinde belirlenen kuyucuklara iki tekrarlı olacak şekilde $6 \mu \mathrm{L}$ hacminde standartlar ve total protein içeriği bilinmeyen 
numuneler eklendi. Bunların üzerine fazla zaman geçirmeden kitle birlikte tedarik edilen Coomassie brillant blue reaktifi multikanal pipetle $300 \mu \mathrm{L}$ hacminde eklendi. Kuyucuklarda bulunan çözeltilerin absorbansları ve kalibrasyon eğrisi aracılığı ile de total protein seviyeleri belirlendi. Elde edilen total protein düzeyleri hücre lizatlarında analizi gerçekleştirilen oksidatif stres ve inflamasyonla ilişkili parametre düzeylerinin hesaplanmasında kullanıldı.

\subsection{Total Antioksidan Statü (TAS) Düzeyleri Analizi}

Son yıllarda bir ortamda bulunan farklı antioksidanların toplam etkisinin belirlenebilmesi için özel yöntemler geliştirilmiştir. Bu yöntemlerde ortama katılan reaktif bir türün, yine ortamda bulunan antioksidanlar tarafından indirgenme/inaktif etme süreci takip edilerek numunenin antioksidan kapasitesi belirlenmeye çalışılmaktadır. Sunulan çalışmada da bu prensiple çalışan ticari bir kit (Rell Assay, Gaziantep, Türkiye) kullanılarak TAS düzeyleri belirlendi. Öncelikle kitle birlikte temin edilen standartlar yardımıyla 5 farklı konsantrasyonda (0,125-0,25-0,5-1-2 mmol trolox) standart çözeltisi hazırlandı. Sonrasında kalibrasyon eğrisi hazırlanarak numunelerdeki TAS düzeyleri belirlendi. Seviyeleri belirlenen TAS düzeyleri ( $\mathrm{mmol}$ Trolox Equivalent/L) her bir numunenenin kendi total protein seviyesine bölünerek mmol Trolox Equivalent/g-protein şeklinde ifade edildi.

\subsection{Total Oksidan Statü (TOS) Düzeyleri Analizi}

Numunelerde TOS düzeylerini belirleyebilmek için, oksidatif strese sebep olabilecek türlerin toplam etkisini belirlemek üzere kullanılan ticari bir kit (Rell Assay, Gaziantep, Türkiye) kullanıldı. Kit protokolünde ifade edilen uygulamalar gerçekleştirildikten sonra numunelerin ve kitle birlikte temin edilen standardın absorbans değerleri belirlendi. Bu absorbans değerleri yardımıyla kit protokolünde verilen formül (TOS $=[(\triangle \mathrm{Absnumune})$ / ( $\Delta$ Absstandart)] *20) aracılığı ile numunelerdeki TOS seviyeleri hesaplandı. Belirlenen TOS sonuçları $\mu \mathrm{M}$ hidrojenperoksit equivalent litre $\left(\mu \mathrm{M} \quad \mathrm{H}_{2} \mathrm{O}_{2}\right.$ Equiv./L) olarak bulundu. Hesaplanan sonuçlar numunelerin kendi total protein seviyelerine bölünerek normalize edildi. TOS düzeyleri $\mu \mathrm{mol} \mathrm{H}_{2} \mathrm{O}_{2}$ Equiv./g protein şeklinde ifade edildi.

\subsection{Oksidatif Stres indeksi (OSI) Seviyelerinin Belirlenmesi}

Bir ortamda bulunan oksidan ve antioksidan türlerin etkileri dikkate alınarak, ortamın oksidatif stres düzeyi (OSI) değerlendirilebilmektedir. Bu amaçla ortamda bulunan oksidan türlerin toplam etkisi (TOS) ve antioksidan türlerin toplam etkisi (TAS) belirlendikten sonra bu veriler birbirlerine oranlanarak sonuca gidilmektedir. Sunulan çalışmada da TOS düzeyleri TAS düzeylerine bölünerek (OSI = [(TOS/TAS) x 100]) numunelerdeki oksidatif stress düzeyleri hesaplanmıştır (Hazman ve Ovalı 2015, Hazman ve Bozkurt 2015).

\section{7 inflamatuvar Stokin (TNF- $\alpha$, IL-16 ve IFN- $\gamma$ ) Seviyelerinin Belirlenmesi}

Krosinin MCF-7 hücrelerinde antiinflamatuvar etkisinin olup olmadığını belirlemek amacıyla, TNF- $\alpha$, IL-1 $\beta$ ve IFN- $\gamma$ seviyeleri hücre lizatlarında multiplate okuyucu cihazı (Biotek, ELx800) yardımıyla 540 nm'de spesifik ticari kitler (Sunred Biotech) aracılığıyla belirlendi. Elde edilen veriler, numunelerin kendilerine ait total protein konsantrasyonlarına bölündü. Böylelikle normalize edilen stokin seviyeleri $\mathrm{ng} / \mathrm{mg}$-protein veya $\mathrm{pg} / \mathrm{mg}$ protein olarak ifade edildi.

\subsection{RNA izolasyonu, cDNA Sentezi ve mRNA Ekspresyon Düzeylerinin Belirlenmesi}

RNA izolasyonu amacıyla her bir deney grubu için 25'lik 5 flaska ekim yapıldı. Çizelge $1^{\prime}$ de belirtilen uygulamalardan 24 saat sonra flasklardaki besiyerleri hücrelere zarar verilmeden alındı. Hücreler $37^{\circ} \mathrm{CPBS}$ ile yıkandı. Sonrasında her bir flaska RNA izolasyonu için tedarik edilmiş olan ticari kitin (Gen Matrix) içeriğinde bulunan lizis tampon çözeltisinden uygun hacimde eklendi. Steril hücre kazıyıcısı (Thermo, cell scraper) kullanılarak flask tabanındaki hücreler lize edildi ve flaskın bir köşesinde toplanarak homojenizasyon kolonlarına aktarıldı. Total RNA izolasyonu kit protokolüne uygun bir şekilde gerçekleştirildikten sonra elde edilen RNA'ların konsantrasyonu ve kalitesi nanodropta (BioTek, Epoch 2) belirlendi. İzole edilen RNA'ların $260 \mathrm{~nm}$ ve 
$280 \mathrm{~nm}^{\prime}$ de elde edilen optik dansiteleri $\left(\mathrm{OD}_{260 / 280}\right)$ oranı 1.7-2,2 arasında olan RNA'lar çalışmada kullanıldı (Hazman et al. 2018).

Elde edilen total RNA'lar kullanılarak komplementari DNA (cDNA) ticari kit (Thermo) yardımıyla sentezlendi. cDNA'ların kalitesi ve çalışıp çalışmadığı, Reverz Transkripsiyon-Polimeraz Zincir Reaksiyonu (RT-PCR) yöntemi ile kontrol gen olarak $\beta$-Aktin aracılığıyla ve melting-curve protokolü uygulanarak belirlendi. Sonrasında RT-PCR yardımıyla p53, Bcl-2, TRAIL1, TRAIL2, Bax genlerine ait mRNA ekspresyon düzeyleri analiz edildi. RT-PCR analizlerinde kullanılan ve analizi gerçekleştirlen genlere spesifik olan primerler (Çizelge 2) literatürdeki çalışmalar taranarak belirlendi (Ersin vd.. 2016, Ulaşlı vd. 2013).

Çizelge 2.Oligonükleotid primer dizileri ve RT-PCR programları

\begin{tabular}{ll}
\hline Gen & Primer Dizisi \\
\hline \multirow{2}{*}{ 3-Aktin } & $\begin{array}{l}\text { F5'CATCGTCACCAACTGGGACGAC'3 } \\
\text { R5'CGTGGCCATCTCTTGCTCGAAG'3 }\end{array}$ \\
\hline \multirow{2}{*}{ p53 } & $\begin{array}{l}\text { F-5'CGGAGGTCGTGAGACGCTG'3 } \\
\text { R5'CACATGTACTTGTAGTGGATGGTGG'3 }\end{array}$ \\
\hline \multirow{2}{*}{ Bax } & $\begin{array}{l}\text { F5'CGCCTCACTCACCATCTGGAA'3 } \\
\text { R5'CCTCAAGACCACTCTTCCCCA'3 }\end{array}$ \\
\hline \multirow{2}{*}{ TRAIL1 } & F5'GAGAAGTCCCTGCACCACGAC'3 \\
\hline \multirow{2}{*}{ TRAIL2 } & R5'CCGGAAAGTTCCTGGTTTGCAC'3 \\
\hline \multirow{2}{*}{ Bcl-2 } & R-5'GTCGTTGTTGAAGCTTCTGTCCA'3 \\
\hline
\end{tabular}

Çizelge 2'de sunulan primerlerden, her bir numuneden elde edilmiş olan CDNA için RT-PCR reaksiyonunda $100 \mathrm{ng}$ düzeyinde kullanıldı. RT-PCR cihazında (Biorad CFX-96) gercekleştirilen analizlerde her bir numunenin amplifikasyon eğrilerine ait döngü eşiği $(C t)$ değerlerinden hareketle, hedef genlerin mRNA ekspresyon düzeylerinin nisbi değişimleri, $2^{-\Delta \Delta c t}$ metodu ile hesaplandı (Pfaffl 2001). Hesaplamalar REST 2009 yazılımı (Qiagen, Germany) kullanılarak yapıldı. mRNA ekspresyon düzeyleri misli olarak azalma ya da artış şeklinde belirlendi. Endojen kontrol olarak beta aktin geni kullanıldı. Her bir örneğe ait beta aktin gen düzeyine göre diğer genlerin ekspresyon düzeylerinde düzeltme (normalizasyon) uygulandı.

\subsection{Istatistiki Analizler}

Laboratuvar analzileri sonucunda derlenen ham veriler ortalama \pm standart sapma olacak şekilde tanımlandı. Yapılan istatistiki değerlendirmelerde SPSS 18 yazılımı tercih edildi. İstatistiki değerlendirmeye, her bir parametreye ait verilerin normal dağılım durumunun belirlenmesiyle başlandı. Normal dağılım gösteren parametrelerde istatistiki fark olup olmadığı ANOVA testi ile belirlendi. Gruplar arası farklılıkların değerlendirilmesinde ise post-test olarak Duncan testi tercih edildi. Normal dağılım göstermeyen parametrelerde gruplar arasında istatistiki fark olup olmadığı Kruskal-Wallis testi ile tespit edildi. Hangi gruplar arasında fark oluştuğu ise Man Whirney $U$ testi ile belirlendi. Çalışmada kullanılan ilgili genlere ait gen ekspresyonu seviyeleri arasındaki istatistiki farklııklar ise REST2007 (Qiagen, Germany) yazılımı kullanılarak belirlendi. İstatistiki düzeyde farklılık gösteren genlere ait ekspresyon düzeyleri grafiklerde $\left(^{*}\right)$ işareti ile gösterildi.

\section{Bulgular}

MCF-7 hücrelerinde krosinin sitotoksisitesini belirleyebilmek için $0.1-6.4 \mathrm{mg} / \mathrm{mL}$ aralığındaki 7 farklı dozu kullanıldı. Krosinin $0.2 \mathrm{mg} / \mathrm{mL}$ ve daha yüksek dozlarda sitotoksisitesinin arttığı görüldü. 1.6-6.4 $\mathrm{mg} / \mathrm{mL}$ aralığındaki dozların ise yüksek sitotoksisiteye sahip olabileceği belirlendi. MTT analizi verilerinden yola çıkılarak hazırlanan Şekil 1 'de krosinin doza bağımlı bir şekilde hücre canlılığını azalttığı gösterilmiştir.

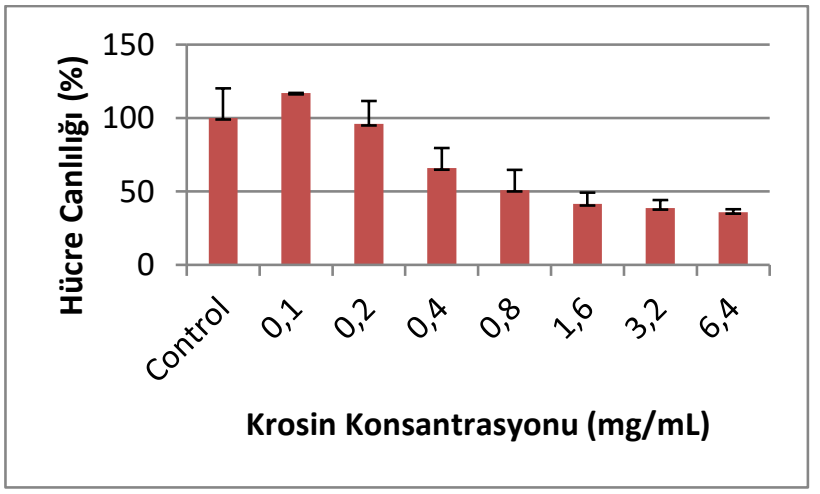

Şekil 1.MCF-7 hücrelerinde krosinin sitotoksisitesi 
Elde edilen veriler bir istatistik programı (Epa Probit Analysis Program, Version 1.5) ile değerlendirilerek, krosinin MCF-7 hücrelerindeki günlük maruziyette akut ortalama toksik ( $\left.\mathrm{LD}_{50}\right)$ dozu $1611.11 \mu \mathrm{g} / \mathrm{mL}, \mathrm{LD}_{0}$ dozu ise $20.17 \mu \mathrm{g} / \mathrm{mL}$ olarak belirlenmişir (Çizelge 3). Sunulan çalışmada belirlenen lethal dozlar arasından yalnızca 2 'si ( $L_{0}$ ve $L_{50}$ dozları) kullanılmıştır. Bu dozların dışında yüksek doz krosin tedavi grubu olan 4. grupta yüksek doz olarak, krosinin LD $_{50}$ dozunun yaklaşık iki katı olan $3200 \mu \mathrm{g} / \mathrm{mL}$ krosin dozu kullanılmıştır.

Çizelge 3. Krosinin MCF-7 hücrelerinde etkili olan lethal dozları

\begin{tabular}{lccc}
\hline & $\begin{array}{c}\text { Krosine ait } \\
\text { lethal dozlar ve } \\
\text { konsantrasyonları } \\
(\mu \mathrm{g} / \mathrm{mL})\end{array}$ & $\begin{array}{c}\text { 95\% Confidence Limits } \\
(\mu \mathrm{g} / \mathrm{mL})\end{array}$ \\
\cline { 3 - 4 } & 20.17 & Lower & Upper \\
\hline $\mathrm{LD}_{0}$ & 72.76 & 0.094 & 94.78 \\
\hline $\mathrm{LD}_{5}$ & 144.21 & 8.35 & 368.34 \\
\hline $\mathrm{LD}_{10}$ & 228.84 & 23,19 & 523.16 \\
\hline $\mathrm{LD}_{15}$ & 1611.12 & 760.313 & 5279.85 \\
\hline $\mathrm{LD}_{50}$ & & & \\
\hline
\end{tabular}

\subsection{Krosinin Oksidatif Stres ve Inflamasyona Etkileri}

MCF-7 hücrelerinde krosinin 3 farklı dozu kullanılarak ( $\mathrm{LD}_{0}, \mathrm{LD}_{50}$ ve $2 \mathrm{xLD}_{50}$ dozları), hem krosinin düşük dozlardaki etkinliği hem de yüksek dozlarda oksidatif stress ve inflamasyona etkileri tespit edilmeye çalışıldı.

Yapılan analizler sonucunda deney grupları arasında en yüksek TAS seviyeleri $(0.781 \mathrm{mmol}$ torolox equiv/g-protein) kontrol grubunde ölçüldü. Deney gruplarına $L_{0}$ dozunda ve $L_{50}$ dozunda $(1.6 \mathrm{mg} / \mathrm{mL})$ krosin uygulandığında TAS seviyelerinde düşüş olduğu ve bu düşüşün istatistiki düzeyde önemli bir fark oluşturduğu belirlendi (Çizelge 4). TOS verileri incelendiğinde ise kontrol grubu ile diğer deney grupları arasında herhangi bir istatistik farklılık belirlenemedi. Oksidatif stress değerlendirilmesinde iyi bir yol gösterici veri olan OSI değerleri incelendiğinde ise oksidatif stres indeksi en düşük çıkan grup kontrol grubu, oksidatif stres indeksi en yüksek çıkan grup ise en yüksek krosin dozunun uygulandığı 4. grup olarak belirlendi.
Çizelge 4. Krosinin MCF-7 hücrelerinde oksidatif strese etkisi

\begin{tabular}{lccc}
\hline $\begin{array}{l}\text { Deney } \\
\text { Grupları }\end{array}$ & $\begin{array}{c}\text { TAS } \\
\text { (mmol } \\
\text { torolox } \\
\text { equiv/g- } \\
\text { protein) }\end{array}$ & $\begin{array}{c}\text { TOS } \\
(\mu \mathrm{mol} \\
\mathbf{H 2 O 2} \\
\text { equiv./g- } \\
\text { protein) }\end{array}$ & $\begin{array}{c}\text { OSI } \\
\text { (Arbitrary Unit) }\end{array}$ \\
\hline $\begin{array}{l}\text { Grup 1 } \\
\text { Kontrol grubu }\end{array}$ & $0.78 \pm 0.08^{\mathrm{c}}$ & $10.2 \pm 0,9$ & $1311.4 \pm 26.6^{\mathrm{a}}$ \\
\hline
\end{tabular}

\begin{tabular}{llll}
\hline Grup 2 & $0.58 \pm 0.04^{\mathrm{a}, \mathrm{b}}$ & $9.8 \pm 0.6$ & $1396.9 \pm 304.5^{\mathrm{b}}$ \\
$\mathrm{LD}_{0}$ dozu & & & \\
tedavi grubu & & & \\
\hline
\end{tabular}

\begin{tabular}{|c|c|c|c|}
\hline $\begin{array}{l}\text { Grup } 3 \\
\text { LD }_{50} \text { dozu } \\
\text { tedavi grubu }\end{array}$ & $0.70 \pm 0.10^{\mathrm{a}}$ & $9.1 \pm 1.4$ & $1596.3 \pm 210.5^{b}$ \\
\hline $\begin{array}{l}\text { Grup } 4 \\
\text { Yüksek doz } \\
\text { tedavi grubu }\end{array}$ & $0.61 \pm 0.09 \mathrm{~b}, \mathrm{c}$ & $9.7 \pm 0.7$ & $1612.1 \pm 78.7^{\mathrm{a}, \mathrm{b}}$ \\
\hline P değeri & $0.001^{*}$ & $0.158^{* *}$ & $0.022^{*}$ \\
\hline $\begin{array}{l}\text { Veriler; ortalama } \pm \text { sta } \\
\text { a, b, c ; Aynı sütünda ve } \\
\text { harfle ile ifade edilmişt } \\
\text { Taşıdığı harf farklı olan } \\
\text { normal dağılım göstere } \\
\text { işareti bulunan ve nor } \\
\text { (Kruskal wallis \& Man } \\
\text { status, OSI: Oxidative s }\end{array}$ & $\begin{array}{l}\text { t sapma şeklinde ver } \\
\text { bir paremetreye ait } \\
\text { ynı harflerden bir vey } \\
\text { olar arasında ise istat } \\
\text { rilere parametrik test } \\
\text { dağılım göstermeye } \\
\text { ney U). Kısaltmalar; } \\
\text { index. }\end{array}$ & $\begin{array}{l}\text { știr. } \\
\text { tistiki farklııkla } \\
\text { ir kaçııı taşıyan } \\
\text { fark vardır. P de } \\
\text { uygulandı (ANO } \\
\text { erilere ise nonf } \\
\text {;:Total antioxidz }\end{array}$ & $\begin{array}{l}\text { Q.05) üst simge halinde } \\
\text { plar arasinda fark yoktur. } \\
\text { inde * işareti bulunan ve } \\
\text { (Duncan). P değerinde ** } \\
\text { metrik testler uygulandı } \\
\text { status, TOS:Total oxidant }\end{array}$ \\
\hline
\end{tabular}

Gruplar arasında istatistiki farklılıklar incelendiğinde ise $L D_{0}$ dozu uygulalan grup 2 ile $L D_{50}$ dozu uygulanan grup 3 OSI değerlerinin kontrol grubundan yüksek ve istatistiki olarak farklı olduğu belirlendi (Çizelge 4). Veriler incelendiği zaman en yüksek OSI değerine sahip olan 4. grubun kontrol grubundan istatistiki olarak farklılık göstermez iken, daha düşük OSI değerine sahip olan diğer grupların (grup 2 ve 3 ) kontrol grubundan istatistiki olarak farklılık gösterdiği belirlendi.

$\mathrm{Bu}$ verilerin bir çelişki oluşturduğu düşünülebilir. Çizelge 4 daha dikkatli incelenirse, özellikle de verilere ait standart sapmalar irdelenirse bu oluşan tezatı açıklamak daha kolay olacaktır. Çünkü kontrol grubuna göre istatistiki fark gösteren ama ortalama değeri çok yüksek olmayan 2. ve 3. grup verilerinin standart sapmaları çok yüksektir. Standart sapmalar dikkate alınarak hesaplar gözden geçirilecek olursa, aslında bu gruptaki numunelerden bazılarının en yüksek OSI değerlerine sahip olduğu anlaşılmaktadır. Bu nedenle grup 2 ve 3'te ortalama OSI değerleri 4. gruba göre yüksek çıkmasa da, kontrol grubuna göre istatistiki fark oluştuğu gözlenmiştir. Krosinin MCF-7 hücrelerinde inflamasyona etkileri incelendiğinde ise 
deney grupları arasında herhangi bir istatistiki farklıık oluşmadığı belirlenmiştir (Çizelge 5).

Çizelge 5.MCF-7 hücrelerine krosinin inflamasyona etkileri

\begin{tabular}{|c|c|c|c|}
\hline Deney Grupları & $\begin{array}{c}\text { IL-1及 } \\
\text { (pg/mg- } \\
\text { protein) }\end{array}$ & $\begin{array}{l}\text { IFN- } \gamma \\
\text { (pg/mg- } \\
\text { protein) }\end{array}$ & $\begin{array}{l}\text { TNF- } \alpha \\
\text { (ng/mg- } \\
\text { protein) }\end{array}$ \\
\hline $\begin{array}{l}\text { Grup } 1 \\
\text { Kontrol Grubu }\end{array}$ & \multicolumn{2}{|c|}{ Kontrol Grubu } & $7,94 \pm 0,81$ \\
\hline \multicolumn{4}{|l|}{$\begin{array}{l}\mathrm{LD}_{0} \text { dozu tedavi } \\
\text { grubu }\end{array}$} \\
\hline \multicolumn{4}{|l|}{$\begin{array}{l}\mathrm{LD}_{50} \text { dozu tedavi } \\
\text { grubu }\end{array}$} \\
\hline \multicolumn{4}{|l|}{$\begin{array}{l}\text { Yüksek doz } \\
\text { tedavi grubu }\end{array}$} \\
\hline $\mathrm{P}$ değeri & $0,069^{* *}$ & $0,150^{* *}$ & $0,208^{*}$ \\
\hline $\begin{array}{l}\text { Veriler; ortalama } \pm \\
\text { parametrelerde grupl } \\
\text { belirlenememiştir. P d } \\
\text { verilere parametrik tes } \\
\text { bulunan ve normal d } \\
\text { uygulandı (Kruskal walli } \\
\text { factor } \alpha \text { and IFN- } \psi \text { :inter }\end{array}$ & $\begin{array}{l}\text { tandart sapma ş€ } \\
\text { r arsında herh } \\
\text { ğerinde * işareti b } \\
\text { ler uygulandı (ANO } \\
\text { ğılım göstermeyen } \\
\text { \& Man whitney U } \\
\text { eron } \gamma \text {, IL-1ß:interle }\end{array}$ & $\begin{array}{l}\text { klinde verilmiştir. } \\
\text { ngi bir istatisti } \\
\text { ulunan ve normal } \\
\text { VA\&Duncan). P değ } \\
\text { verilere ise nonp } \\
\text { Kısaltmalar; TNF-c } \\
\text { ıkin } 1 \beta \text {. }\end{array}$ & $\begin{array}{l}\text { Analizi yapılan } \\
\text { fark varlığı } \\
\text { dağılım gösteren } \\
\text { erinde }{ }^{* *} \text { işareti } \\
\text { rametrik testler } \\
: \text { tumor necrosis }\end{array}$ \\
\hline
\end{tabular}

\subsection{Krosinin Apoptoz ve Proliferasyona Etkileri}

Krosinin MCF-7 hücrelerinde apoptoz (p53, bax, TRAIL1 ve TRAIL 2) ve proliferasyona (Bcl-2) etkisi, analizi gerçekleştirilen genlere ait her bir grubun mRNA ekspresyon düzeylerinin kontrol grubu ile kıyaslanması sonucu belirlendi. MCF-7 hücrelerine $L D_{0}$ dozunda ve $L_{50}$ dozundan daha yüksek dozda krosin uygulanması durumunda TRAIL1 ve proapoptotik bax gen ekspresyonlarının kontrol grubuna gore istatistiki olarak anlamlı düzeyde uyarıldığı (Şekil.2A ve Şekil.2C) görüldü. MCF-7 hücrelerine $L_{50}$ dozunda krosin uygulandığında ise p53 ve TRAIL 2 genlerine ait ekspresyon seviyelerinin kontrol grubuna göre istatistiki düzeyde farklılık gösterdiği belirlendi (Şekil 2).

\section{Tartışma ve Sonuç}

Kanser etiyolojisinde oluşan hücresel hasarın önemli sebepleri arasında oksidatif stres ve inflamasyon aracılığıyla şekillenen apoptoz da sayılmaktadır. Kanser gelişimi sırasında, özellikle de ileri evrelerde organizmada immun sistemin zayıflaması ile oksidatif stres ve inflamasyonda artış gözlenir. Bu
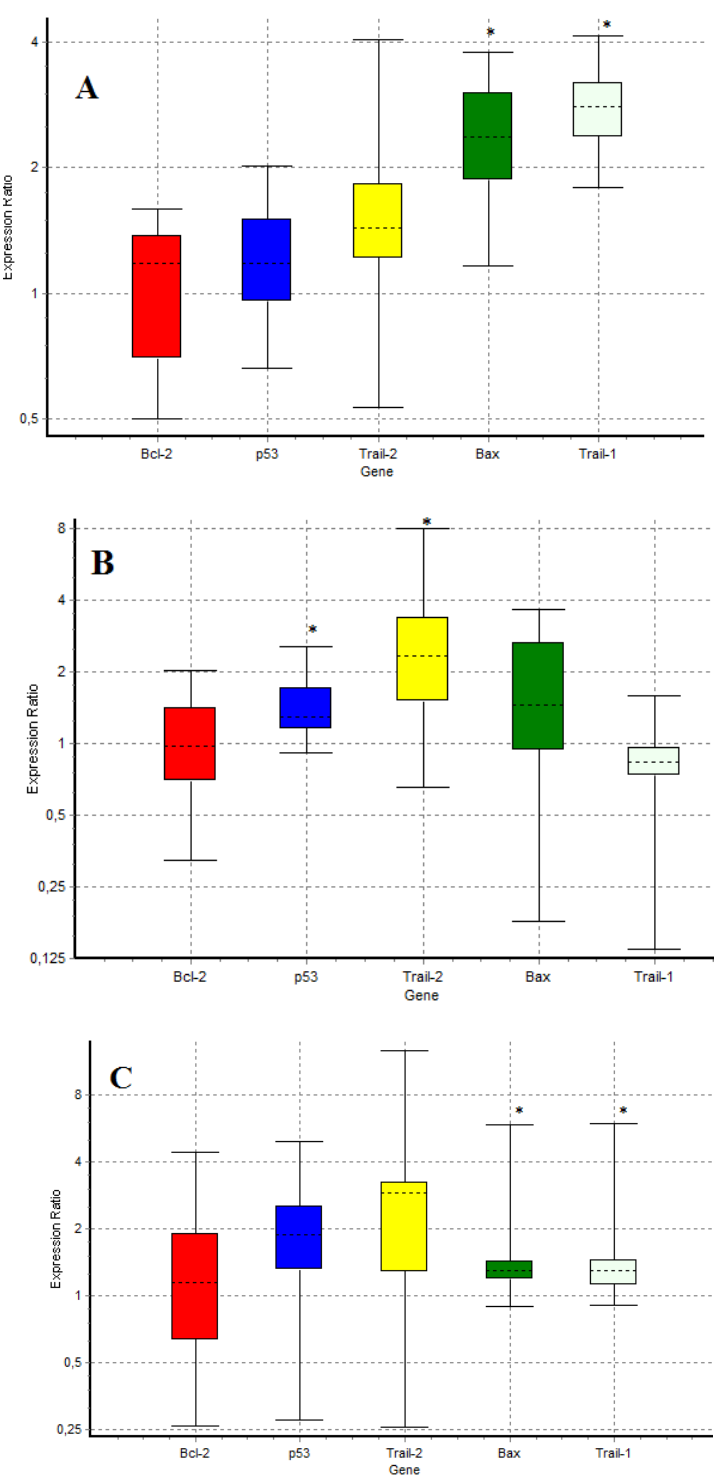

Şekil 2. Krosinin MCF-7 hücrelerinde apoptoz ve proliferasyona etkisi

Veriler; ortalama \pm standart hata şeklinde verilmiştir $(n=5)$. Krosinin MCF-7 hücrelerinde apoptoz ve proliferasyona etkisi, analizi gerçekleştirilen genlere ait her bir grubun mRNA ekspresyon düzeylerinin kontrol grubu ile kıyaslanması sonucu belirlendi. $\mathrm{A}$; kontrol grubu ile $\mathrm{LD}_{0}$ dozu uygulanan 2. grubun kıyaslamasını, $B$; kontrol grubu ile $\mathrm{LD}_{50}$ dozu uygulanan 3 . grubun kıyaslamasını, $C$; kontrol grubu ile $\mathrm{LD}_{50}$ dozunun iki katı doz uygulanan 4 . grubun kıyaslamasını göstermektedir. $\left({ }^{*}\right)$ : Kontrol grubuna gore istatistiki olarak farklılık gösteren parametreleri göstermektedir $(p<0.05)$

açıdan değerlendirildiğinde vücudun direncinin artırılması için antioksidan takviye önemli olabilir. Ama takviyenin kanser hücrelerinin üremesine de katkı yapabileceği düşünülürse, çok dikkatli ve bilinçli bir şekilde yapılması önem arzetmektedir. Bu nedenle antioksidan maddelerin kanser hücrelerinde etkilerinin incelenmesi ve bilim dünyasıyla paylaşılması kanser tedavisinde yeni yaklaşımlar geliştirilmesine katkı sunabilir. 
Krosin ve diğer antioksidanlar düşük dozlarda koruyucu etkiler gösterirken, yüksek dozlarda toksisite gösterebilir. Antioksidanların yüksek dozlarda toksisite oluşturması antioksidatif stres olarak da ifade edilebilir. Antioksidanların yoğun kullanımı ile oluşan bu toksisitenin nedenlerinden biri, hücre membranı ve ara bölüklerinde bulunan doymamış bağlar ve/veya aktif gruplar bulunduran biyomoleküller ile biyoaktif metabolitler olan antioksidanların etkileşime girmesi olabilir. Böylelikle antioksidanlar hücresel moleküllere/yapılara zarar vererek antioksidatif stres oluşturuyor olabilir. Nitekim kanser hücrelerinde birçok antioksidan etkili aktif maddenin düşük dozlarda proliferasyonu artırırken, yüksek dozlarda antikanserojen etkili olabileceğini göstermektedir (Lu et al. 2015, Fanayi et al. 2016). Krosinin antikanserojenik etkilerinin oluşmasında rol oynayan apoptozun uyarılmasında oksidatif stres ve/veya inflamasyon da etkili olabilir. Bu bağlamda sunulan çalışma ile krosinin MCF-7 hücrelerinde sitotoksitesinin belirlenmesini yanında aynı zamanda farklı dozlardaki krosinin MCF-7 hücrelerinde oksidatif stres ve inflamasyon aracılı apoptoza etkilerinin nasıl olduğu aydınlatılmaya çalışıımıştır.

MCF-7 hücreleriyle yapılan çalışmalarda krosinin $\mathrm{LD}_{50}$ dozuyla ilgili farklı bilgiler mevcuttur. Lu vd. (2015)'nın yaptığı bir çalışmada MCF-7 hücreleri ile krosinin farklı dozlarının 24 ve 48 saat inkübe edilmesi sonucunda $\mathrm{LD}_{50}$ dozları belirlenmiştir. 24 saatlik inkübasyonda krosinin $\mathrm{LD}_{50}$ dozu $60 \mu \mathrm{g} / \mathrm{mL}$, 48 saat sonunda ise $12.5 \mu \mathrm{g} / \mathrm{mL}$ bulunduğu ifade edilmektedir. Literatürde Lu vd. (2015)'nın bulduğu krosin $\mathrm{LD}_{50}$ dozu $(60 \mu \mathrm{g} / \mathrm{mL}$ ) ile sunulan çalışmada bulunan $\mathrm{LD}_{50}$ dozu $(1611 \mu \mathrm{g} / \mathrm{mL})$ arasında büyük farklııklar vardır. Bunun sebebi çalışmalarda kullanılan krosinin saflık oranlarının farklı olması ve uygulama şekilleri ile ilgili olabilir. Nitekim yapılan başka bir çalışmada ise MCF-7 hücrelerinde krosinin $\mathrm{LD}_{50}$ dozunun $3.5 \mathrm{mg} / \mathrm{mL}$ olduğu belirtilmektedir (Fanayi et al. 2016). Sunulan çalışmada ise yapılan MTT analizleri sonucunda MCF-7 hücrelerinde krosinin LD LD $_{50}$ dozu $1611 \mu \mathrm{g} / \mathrm{mL}$ (1.611 mg/mL) bulunmuştur. Elde edilen bulgular daha önce literatürde belirlenen doz aralığında olduğu için ideal kabul edilebilir.

Krosin gibi antioksidan maddeler yüksek dozlarda antikanserojen etkinlik gösterirken, düşük dozlarda hem vücut hücrelerinin hem de kanser hücrelerinin proliferasyonunu artırabilir. Bu durum ise kanser hücrelerinin üreme yeteneğinin normal hücrelere göre daha ileri olduğu göz önüne alınırsa kanserin daha da ilerlemesine yol açabilir. Bununla beraber sunulan çalışmada, düşük doz krosin uygulamalarının proliferasyonu etkilemeden


$\mu \mathrm{g} / \mathrm{mL}$ ) krosin uygulanan grupta TAS düzeylerinin kontrol grubuna göre azalarak oksidatif stresi artırdığı (Çizelge 4) ve büyük olasılıkla bu nedenle apoptozu uyardığı söylenebilir. Nitekim LD $_{0}$ dozu uygulanan grupta oksidatif stresle beraber apoptotik genler olan bax ve TRAIL1 mRNA ekspresyon seviyelerinin uyarıldığı (Şekil 2A) gösterilmiştir. Literatürde yapılan çalışmalarda bu bulgumuzu destekler niteliktedir. Bakshi vd. (2016)'a göre $20 \mu \mathrm{g} / \mathrm{mL}$ dozunda krosin uygulanan MCF-7 hücrelerinde bax, caspase 3 gibi apoptotic genleri uyarılabileceği rapor edilmektedir. Bu veriler düşük dozlarda bile meme kanserli hastalarda krosinin ve krosin içerikli ürünlerin risk oluşturmayacağını göstermektedir. Bununla birlikte düşük dozlardaki krosinin sağlıklı hücreler üzerindeki etkisinin ayrıca değerlendirilmesi / araştırılması yararlı olacaktır.

Sunulan çalışmada $L D_{50}$ dozu uygulanan grupta da TAS düzeylerinin düşmesine bağlı bir şekilde oksidatif stresin ve buna bağlı olarak apoptotik genler olan p53 ve TRAIL2 mRNA ekspresyon düzeylerinin uyarıldığı (Şekil 2B) belirlendi. Nitekim yapılan çalışmalar p53 uyarılmasında da etkin rol oynayabilen sitozolik ve mitokondriyal kaynaklı reaktif oksijen türlerinin apoptozun uyarılmasında etkili olabileceği ifade edilmektedir (Lu et al. 2015, Nasimian et al. 2020). Bununla birlikte daha yüksek krosin dozu uygulanan deney grubunda (grup 4) oksidatif stress ve inflamasyonla ilgili kontrol grubuna göre bir farklılık görünmesede apoptozun bax ve TRAIL1 aracılığı ile uyarıldığı görüldü. $\mathrm{Bu}$ durum yüksek doz krosin uygulamalarında MCF-7 hücrelerinde apoptozun oksidatif stress ve 
inflamasyon dışında başka bir hücresel etki sonucu şekillenmiş olabileceğini akla getirmektedir. Örneğin apoptozun şekillenmesinde hatalı protein katlanmalarına cevap olarak gelişebilen endoplazmik retikulum (ER) stresi rol oynamış olabilir. Ama bunun daha net olarak ifade edilebilmesi için daha ileri çalışmalara ihtiyaç vardır.

Çeşitli hücre hatlarıyla yapılan çalışmalarla krosinin proliferasyonu baskılayarak (Bakshi et al. 2016, Chryssanthi et al. 2007, Hire et al. 2017) antikanserojen etkileri olabileceği de ifade edilmektedir. Fakat sunulan çalışmada ne düşük dozlarda ne de yüksek dozlarda krosinin proliferatif bir gen olan Bcl-2 mRNA ekspresyon düzeylerini etkilemediği belirlenmiştir. $\mathrm{Bu}$ tezatın nedeni çalışmalarda kullanılan farklı krosin dozu (Bakshi et al. 2016) veya proliferasyon düzeylerinin gösterilmesinde kullanılan parametrelerin farklı olmasıyla (Chryssanthi et al. 2007) açıklanabilir.

Elde edilen tüm veriler birlikte değerlendirildiğinde krosinin MCF-7 hücrelerinde $L_{0}$ ve $L_{50}$ dozlarında proinflamatuvar stokin düzeylerini etkilemeksizin oksidatif stresi artırarak apoptozu uyardığı ve böylelikle sitotoksisiteye sebep olduğu sonucuna ulaşılmıştır. Hem MCF-7 hücrelerinde hem de diğer hücre hatlarında krosinin antikanser etkinliğinin daha iyi anlaşılabilmesi için metabolizmayı etkileyen önemli sinyal yollarına ve apoptozise etkilerinin daha ayrıntılı bir şekilde araştırılması gerekmektedir. Ayrıca hücre kültüründen elde edilen bulguların, deney hayvanlarında oluşturulacak modellemeler ile doğrulanması krosinin kanser tedavisinde olası yararlarını açıklamak adına faydalı olabilir.

\section{Teşekkür}

Sunulan bu çalışma Afyon Kocatepe Ünüversitesi Bilimsel Araştırma Projeleri Komisyonu tarafından (Proje no: 16.KARIYER.160) desteklenmiştir. Ayrıca sunulan çalışmadaki bulguların bir kısmı 23-25 Ağustos 2017 tarihlerinde Roma-italya'da düzenlenen “IV. International Multidisciplinary Congress of Eurasia (IMCOFE)" kongresinde sözlü bildiri şeklinde sunulmuş ve özet bildiri şeklinde kongre kitabında yayınlanmıştır.

\section{Kaynaklar}

Adali, F., Gonul, Y., Aldemir, M., Hazman, O., Ahsen, A., Bozkurt, M.F., Sen, O.G., Keles, I., Keles, H., 2016. Investigation of the Effect of Krosin Pre-Treatment on Renal Injury Induced by Infrarenal Aortic Occlusion. Journal of Surgical Research, 203,145-53.

Assimopoulou, A.N., Sinakos, Z., Papageorgiou, V.P., 2005. Radical scavenging activity of Crocus sativus L. extract and its bioactive constituents. Phytotherapy Research, 19, $997-1000$.

Bakshi, H.A., Hakkim, F.L., Sam, S., 2016. Molecular Mechanism of Crocin Induced Caspase Mediated MCF-7 Cell Death: In Vivo Toxicity Profiling and Ex Vivo Macrophage Activation. Pacific Organization for Cancer Prevention, 17,1499-506.

Bradford, M.M., 1976. A rapid and sensitive method for the quantitation of microgram quantities of protein utilizing the principle of protein-dye binding. Analytical biochemistry, 7, 248-54.

Chryssanthi, D. G., Fotini N. L., Gregoris, I., Adamantia, P., Nikos, K. K., Paul, C., 2007. Inhibition of breast cancer cell proliferation by style constituents of different Crocus species. Anticancer Research, 27, 357-362.

Ersin, G., Çelik, S., Ulasli, S.S., Özyürek, A., Hazman, Ö., Günay, S., Özdemir, M., Ünlü, M., 2016. Comparison of the Anti-inflammatory Effects of Proanthocyanidin, Quercetin, and Damnacanthal on Benzo(a)pyrene Exposed A549 Alveolar Cell Line, Inflammation, 39, 744-751.

Escribano, J., Alonso, G.L., Coca-Prados, M., Fernandez, J.A., 1996. Krosin, safranal and picrokrosin from saffron (Crocus sativus L.) inhibit the growth of human cancer cells in vitro. Cancer Letters, 100, 23-30.

Fanayi, A.R., Changizi, V., Safa, M., 2016. Effect of krosin and doxorubicin/radiation on the breast cancer cell line, Michigan Cancer Foundation, Bioscience biotechnology research communications, 9, 428-434.

Garcia-Olmo, D.C., Riese, H.H., Escribano, J., Ontanon, J., Fernandez, J.A., Atienzar, M., Garcia-Olmo, D., 1999. Effects of longterm treatment of colon adenocarcinoma with crosin, a carotenoid from saffron (Crocus sativus L.): an experimental study in the rat. Nutrition and Cancer, 35, 120-126. 
Hazman, Ö., Aksoy, L., Büyükben, A., 2016. Effects of crosin on experimental obesity and type-2 diabetes. Turkish Journal of Medical Sciences, 46, 1593-1602.

Hazman, Ö., Bozkurt, M.F., Fidan, A.F., Uysal, F.E., Çelik, S., 2018. The Effect of Boric Acid and Borax on Oxidative Stress, Inflammation, ER Stress and Apoptosis in Cisplatin Toxication and Nephrotoxicity Developing as a Result of Toxication. Inflammation, 41, 1032-1048.

Hazman, Ö., Bozkurt, M.F., 2015.Anti-inflammatory and Antioxidative Activities of Safranal in the reduction of Renal Dysfunction and Damage that Occur in Diabetic Nephropathy. Inflammation, 38, 1537-45.

Hazman, Ö., Ovalı, S., 2015. Investigation of the AntiInflammatory Effects of Safranal on High-Fat Diet and Multiple Low-Dose Streptozotocin Induced Type 2 Diabetes Rat Model, Inflammation, 38, 1012-9.

Hazman, Ö., Sarıova, A., Bozkurt, M.F., Ciğerci, I.H., 2021. The anticarcinogen activity of $\beta$-arbutin on MCF-7 cells: Stimulation of apoptosis through estrogen receptor- $\alpha$ signal pathway, inflammation and genotoxicity. Molecular and Cellular Biochemistry, 476, 349-360.

Hire, R.R., Srivastava, S., Davis, M.B., Kumar Konreddy, A., Panda, D., 2017. Antiproliferative Activity of Crocin Involves Targeting of Microtubules in Breast Cancer Cells. Scientific Reports, 24, 44984.

Hoshyar, R., Mollaei, H., 2017. A comprehensive review on anticancer mechanisms of the main carotenoid of saffron, krosin. The Journal of Pharmacy and Pharmacology, 69, 1419-1427.

Kianbakht, S., Hajiaghaee, R., 2011. Anti-hyperglycemic Effects of Saffron and its Active Constituents, Krosin and Safranal, in Alloxan-Induced Diabetic Rats, Journal of Medicinal Plants, 39, 82-89.

Lee, I.A., Lee, J.H., Baek, N.I., Kim, D.H., 2005.Antihyperlipidemic effect of crosin isolated from the fructus of Gardenia jasminoides and its metabolite crocetin. Biological and Pharmaceutical Bulletin, 28, 2106-2110.

Liakopoulou-Kyriakides, M., Skubas, Al., 1990. Characterization of the platelet aggregation inducer and inhibitor isolated from Crocus sativus, Biochemistry international, 22,103-10.

Lu, P., Lin, H., Gu, Y., Li, L., Guo, H., Wang, F., Qiu, X., 2015. Antitumor effects of crosin on human breast cancer cells. International Journal of Clinical and Experimental Medicine, 8, 20316-22.

Nasimian, A., Farzaneh, P., Tamanoi, F., Bathaie, S.Z., 2020. Cytosolic and mitochondrial ROS production resulted in apoptosis induction in breast cancer cells treated with Crocin: The role of FOXO3a, PTEN and AKT signaling. Biochemical pharmacology, 177, 113999.

Ozkececi, Z.T., Gonul Y., Yuksel Y., Karavelioglu A., Tunay K., Gulsari Y., Cartilli O., Hazman O., Bal A. 2016. Investigation of the effect of safranal and crocin pretreatment on hepatic injury induced by infrarenal aortic occlusion. Biomedicine and Pharmacotherapy, 83, 160-166.

Pfaffl, M.W., 2001. A new mathematical model for relative quantification in real-time RT-PCR. Nucleic acids research, 29, e45.

Rajaei, Z., Hadjzadeh, M.A., Nemati, H., Hosseini, M., Ahmadi, M., Shafiee, S., 2013. Antihyperglycemic and antioxidant activity of crosin in streptozotocininduced diabetic rats. Journal of Medicinal Food, 16, 206-10.

Shirali, S., Bathaine, S., Nakhjavani, M., 2013. Effect of crosin on the insülin Resistance and lipid profile of streptozotocin-induced diabetic rats. Phytotherapy Research, 27, 1042- 1047.

Soeda, S., Ochiai, T., Paopong, L., Tanaka, H., Shoyama, Y., Shimeno, H., 2001. Crosin suppresses tumor necrosis factor-alpha-induced cell death of neuronally differentiated PC-12 cells. Life Sciences, 69, 2887-98.

Sung, H., Ferlay, J., Siegel, R.L., Laversanne, M., Soerjomataram, I., Jemal, A., Bray, F., 2021. Global Cancer Statistics 2020: GLOBOCAN Estimates of Incidence and Mortality Worldwide for 36 Cancers in 185 Countries. CA: A Cancer Journal for Clinicians, 71, 209-249.

Ulasli, S.S., Celik, S., Gunay, E., Ozdemir, M., Hazman, O., Ozyurek, A., Koyuncu, T., Unlu, M., 2013. Anticancer effects of thymoquinone, caffeic acid phenethyl ester 
and resveratrol on A549 non-small cell lung cancer cells exposed to benzo(a)pyrene. Asian Pacific Journal of Cancer Prevention, 14, 6159-64. 